(C) Паньків В. Р.

УДК 631.331.85

АНАЛІЗ ПРОЦЕСУ ТРАНСПОРТУВАННЯ МАТЕРІАЛУ

КОМБІНОВАНИМ ГВИНТОВИМ ТРАНСПОРТЕРОМ

В. Р. ПАНЬКІВ, аспірант

Тернопільський національний технічний університет імені Івана Пулюя

E-mail: Vitaliipankiv25@gmail.com

Анотація. Гвинтові транспортери, у якості транспортних механізмів застосовують в аграрній сфери виробництва, переробній та харчовій галузях промисловості, специфіка яких обумовлена наявністю широкої гами технологічних прочесів збирання та переробки продукції рослинництва. Удосконалення існуючих конструкцій гвинтових транспортних механізмів $i$ обгрунтування їх рачіональних параметрів і режимів роботи дозволяє істотно підвищити продуктивність роботи та надійність виконання технологічних операцій. Наведено результати аналітичних і експериментальних досліджень комбінованого гвинтового транспортера-подрібнювача коренеплодів, який виконано у вигляді напрямного кожуха в якому розміщено шнековий конвеєр, між витками якого встановлено ножі-подрібнювачі. За результатами експериментальних досліджень отримано рівняння регресі, яке характеризує зміну продуктивності роботи удосконаленого комбінованого гвинтового транспортера залежно від параметрів шнекового конвеєра. Встановлено, що у заданих межах варіювання вхідних факторів (частоти обертання шнекового конвеєра $100 \leq n_{k} \leq 300$ об/хв; діаметра шнекового конвеєра $0,12 \leq D_{k} \leq 0,2 \mathrm{M}$; кроку шнека 0,05 $\leq T_{1} \leq 0,11 \mathrm{M}$ ), продуктивність роботи знаходиться в діапазоні від 0,5 до 5,0 кг/с. Результати досліджень є подальшим кроком 3 розробки методики обгрунтування параметрів транспортних машин.

Ключові слова: шнек, коефічієнт заповнення, горизонтальний конвеєр, факторний експеримент, емпірична модель, частота обертання, діаметр, крок.

Актуальність. В аграрному виробництві гвинтові транспортери (шнекові конвеєри) призначені для транспортування (переміщення в горизонтальному, похилому та вертикальному напрямках) продуктів аграрного виробництва, наприклад, коренеплодів, зерна, кормових сумішей тощо. При цьому шнекові конвеєри за ознакою своїх конструктивних особливостей можуть одночасно виконувати суміжні функції - змішування продуктів, подрібнення або дроблення матеріалів, дозування тощо [1, с. 107-109; 2, с. 1, 4]. 
(C) Паньків В. P.

Як окремий технологічний елемент транспортних механізмів шнекові конвеєри застосовуються в конструктивних схемах машин агропромислового комплексу - зерно- та коренезбиральних комбайнах, машин для внесення добрив, дробарках, протруювачах насіння тощо [2], а також в конструкціях машин для перевантаження або переміщення матеріалів в зв’язку 3 їх надійністю роботи, простотою технічного обслуговування, спроможністю завантаження та повного, або часткового розвантаження матеріалу в будьякому місці технологічної лінії [3, с. 147, 169, 403, 610].

Поєднання виконання однієї або декількох технологічних операцій, поряд 3 транспортуванням матеріалів, яке притаманне комбінованим гвинтовим транспортерам, є їх визначальною ознакою.

Тому розробка удосконалених конструкцій комбінованих гвинтових транспортерів, які забезпечують одночасне подрібнення та транспортування матеріалів і обгрунтування раціональних параметрів робочих органів транспортних механізмів, є важливим науковим завданням.

Аналіз останніх досліджень та публікацій. Гвинтові транспортери, які виконано на основі шнекових конвеєрів є складовою частиною комплексної механізації і автоматизації виробничих процесів. За даними [4, с. 104] їх питома вага в вантажно-розвантажувальних операціях становить 40-45 \%. Проведений аналіз сучасного стану функціонування гвинтових транспортних механізмів [5, с. $9-10 ; 6$, с. 199-200; 7, с. 57-58; 8, с. 238-239] показав, що існують значні передумови для проведення подальших наукових робіт, які спрямовані на розробку, дослідження та впровадження в виробництво енергозберігаючих, високотехнологічних комбінованих гвинтових транспортерів, які забезпечують ефективне виконання суміжних функціональних операцій, як транспортування, так і одночасного подрібнення сировини з продуктів сільськогосподарського виробництва в процесі її переробки.

Мета дослідження - підвищення технологічних показників процесу одночасного подрібнення та транспортування коренеплодів шляхом розробки 
(C) Паньків В. P.

та обгрунтування параметрів робочих органів комбінованого гвинтового транспортера-подрібнювача.

Матеріали і методи дослідження. Удосконалення існуючих конструкцій гвинтових транспортних механізмів i обгрунтування їх раціональних параметрів і режимів роботи дозволяє підвищити продуктивність роботи та надійність виконання технологічних операцій. Тому під час їх проектування слід враховувати специфічні технічні вимоги та функціонально-експлуатаційні характеристики машин для виконання відповідних робіт, а також особливості транспортно-технологічних процесів, агробіологічні та фізико-механічні властивості продуктів, які підлягають транспортуванню [5, с. 25-29].

Критеріями, які характеризують економічну ефективність застосування транспортних машин або механізмів, є продуктивність їх роботи, енергозатрати процесу транспортування матеріалів, надійність i стабільність виконання технологічного процесу, ресурс роботи тощо [9, с. 125-126].

На основі проведеного аналізу технологічних процесів і показників транспортування матеріалів аграрного виробництва, нами запропоновано конструктивну схему удосконаленого комбінованого гвинтового транспортера [10, с. 61]. Присутність одночасних технологічних операцій транспортування та подрібнення матеріалу (коренеплодів), або наявність ножів-подрібнювачів, які встановлено в міжвитковому просторі шнекового конвеєра по гвинтовій лінії вносить суттєві корективи в існуючі методики та методи розрахунку гвинтових механізмів. За рахунок збільшення сумарної швидкості осьового переміщення подрібнених частинок коренеплодів спіральними витками шнека та ножамиподрібнювачами, значно підвищується продуктивність роботи комбінованого гвинтового транспортера.

Обгрунтування раціональних параметрів комбінованого гвинтового транспортера проведено шляхом аналітично-експериментального дослідження його продуктивності, яка в загальному аспекті визначається продуктивністю роботи шнекового конвеєра. При цьому критерієм технологічності робочого процесу одночасного подрібнення та транспортування коренеплодів шнековим 
(C) Паньків В. P.

конвеєром буде умова за якої пропускна здатність $Q_{k}(t)$ шнекового конвеєра повинна бути не меншою за подачу коренеплодів $W_{k}(t)$ за проміжок часу $t$.

В результаті аналітичного аналізу одночасного процесу подрібнення та транспортування коренеплодів отримано умову раціонального функціонування комбінованого гвинтового транспортера [10, с. 66]

$$
\begin{aligned}
& d Q_{k}=\frac{\pi n_{k} D_{k}^{2} \rho_{k} \psi_{\alpha}\left(T_{1}+n \Delta T\right) k_{a} k_{y}}{240} \times \\
& \times\left(1-\frac{1}{2 \pi k_{d}^{2}}\left[\begin{array}{l}
\frac{1}{\pi}+\frac{4 \Omega \delta_{c} z\left(k_{d}-1\right) k_{d}}{n\left[2 T_{1}+\Delta T(n-1)\right] D_{k}}+\frac{D_{k}}{k_{d}} \theta_{1} \delta_{n}\left(n_{z} n-1\right) \times \\
\left.\times\left(\begin{array}{l}
D_{k} k_{d}\left[\pi-\operatorname{tg} \gamma_{n}\left(k_{d}-1\right)\right]\left(\left(k_{d}-1\right)\right) \cos \gamma_{n}- \\
\frac{-\delta_{n}\left[\left[0,5 \pi-\operatorname{tg} \gamma_{n}\left(k_{d}-1\right)\right] \operatorname{tg} \alpha_{n} \cos \gamma_{n}-2\left(k_{d}-1\right)\right]}{D_{k}^{2} n_{z} n\left[2 T_{1}+\Delta T(n-1)\right] \cos \gamma_{n}}-\frac{k_{d} \Theta}{D_{k} \delta_{n}}
\end{array}\right]\right)
\end{array}\right) d t \geq,\right. \\
& \geq \frac{\lambda_{u} \rho_{k} \pi\left(d_{1 z}-a^{\prime}\right)^{2} \sqrt{1,6 g d_{1 z}\left(2 h_{1 z}+d_{2 z} \sin \alpha_{k}\right)}}{2 \sqrt{d_{1 z}}} d t
\end{aligned}
$$

де $n_{k}$ - частота обертання шнека, об/хв; $D_{k}-$ зовнішній діаметр шнека, м; $\rho_{k}-$ об’ємна маса вантажу, кг/м³ $\psi_{\alpha}$ - коефіцієнт кута нахилу шнекового конвеєра до горизонту; $T_{1}$ - крок першого спірального витка, м; $n$ - кількість $T_{i}$-х кроків, шт.; $\Delta T$ - інтервал приросту кроку, м; $k_{\alpha}-$ коефіцієнт, який показують ступінь впливу кута підйому $\alpha$ гвинтової лінії по середньому радіусу останнього витка шнека; $k_{y}$ - коефіцієнт ущільнення подрібнених коренеплодів витками шнека; $k_{d}$ - коефіцієнт співвідношення; $\theta_{1}$ - кількість ножів-подрібнювачів між двома суміжними витками, шт.; $\delta_{n}$ - товщина ножа, м; $n_{z}-$ кількість витків кожного $T_{i}$-го кроку, шт.; $\gamma_{n}-$ кут між висотою ножа та його ребром, град.; $\alpha_{n}-$ кут скосу бічної грані ножа, град.; $\lambda_{u}-$ коефіцієнт опору вантажу; $d_{1 z}, d_{2 z}-$ зведений діаметр верхнього та нижнього отвору вихідної горловини бункера, м; $a^{\prime}$ - середній поперечний розмір коренеплодів, м; $h_{1 z}-$ висота склепіння, м; $\alpha_{k}$ - кут нахилу площини нижнього отвору до горизонту, град.; $d_{m}$ - діаметра 
(C) Паньків В. P.

труби барабана шнека, м; $a$ - верхня основа трапеції форми ножа, м;

$$
\begin{aligned}
& \Omega=\sqrt{T_{1}^{2}+0,25\left(D_{k}+d_{m}\right)^{2}}+\sqrt{T_{2}^{2}+0,25\left(D_{k}+d_{m}\right)^{2}}+\ldots+\sqrt{T_{i}^{2}+0,25\left(D_{k}+d_{m}\right)^{2}}= \\
& =\sqrt{T_{1}^{2}+0,25\left(D_{k}+d_{m}\right)^{2}}+\sqrt{\left(T_{1}+\Delta T\right)^{2}+0,25\left(D_{k}+d_{m}\right)^{2}}+ \\
& +\ldots+\sqrt{\left[T_{i}+\Delta T(n-1)\right]^{2}+0,25\left(D_{k}+d_{m}\right)^{2}} \\
& \Theta=\left[\left(\pi \arcsin \frac{a}{d_{m}} / 180\right)+\frac{a}{d_{m}} \cos \arcsin \frac{a}{d_{m}}\right] .
\end{aligned}
$$

3 врахуванням геометричного коефіцієнта $k_{n}[11$, с. 74] формула для визначення продуктивності роботи шнекового конвеєра набуде вигляду

$$
d Q_{k}=0,125 D_{k}^{2} \rho_{k} \psi_{\alpha} k_{a} k_{y}\left(1-k_{n}\right)\left(T_{1}+n \Delta T\right)\left(\frac{d \varphi_{k}}{d t}\right) d t .
$$

Встановлено, що продуктивність роботи $Q_{k}$ комбінованого гвинтового транспортера знаходиться межах $Q_{k}=0,6 \ldots 4,6$ кг/с $[11$, с. 78], при цьому залежно від параметрів шнекового конвеєра має прямо пропорційний функціональний характер зміни - зі збільшенням діаметра $D_{k}$, кроку $T$, частоти обертання $n_{k}$ i інтервалу приросту кроку $\Delta T$ гвинтового конвеєра продуктивність роботи $Q_{k}$ збільшується. Домінуючими факторами, які мають значний вплив на приріст продуктивності роботи $Q_{k} \in$ частота обертання $n_{k}$ та діаметр $D_{k}$ шнекового конвеєра.

Для перевірки адекватності теоретичних досліджень продуктивності роботи $Q_{k}$ проведено експериментальні дослідження експериментальної установки комбінованого гвинтового транспортера, загальний вигляд якої наведено на рис. 1.

Для отримання емпіричного рівняння регресії, яке характеризує зміну продуктивності роботи $Q_{k e}$ макетного зразка експериментальної установки залежно від параметрів шнекового конвеєра, реалізували планований трифакторний експеримент типу ПФЕ $3^{3}$, при цьому незалежними змінними факторами приймали: частоту обертання шнека $100 \leq n_{k} \leq 300$ об/хв; діаметр 
(C) Паньків В. P.

шнека $0,12 \leq D_{k} \leq 0,2$ м; крок шнека $0,05 \leq T_{1} \leq 0,11$ м.
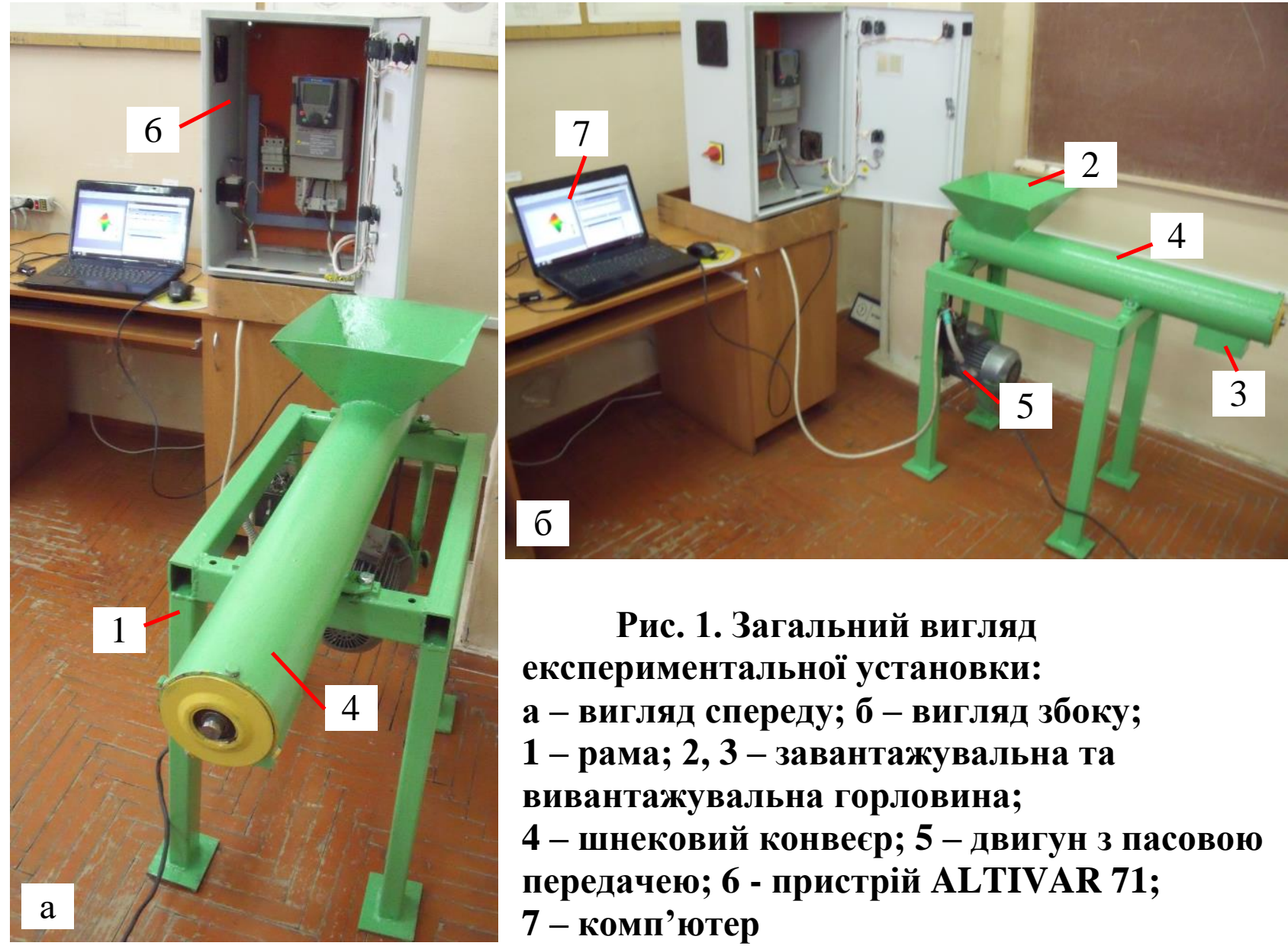

Рис. 1. Загальний вигляд експериментальної установки: а - вигляд спереду; б - вигляд збоку; 1 - рама; 2, 3 - завантажувальна та вивантажувальна горловина; 4 - шнековий конвеср; 5 - двигун 3 пасовою передачею; 6 - пристрій ALTIVAR 71; 7 - комп'ютер

Трифакторний експеримент типу ПФЕ $3^{3}$ провели на трьох рівнях варіювання факторами. Результати кодування факторів та рівні їх варіювання наведено в табл.1.

1. Результати кодування факторів та рівні їх варіювання

\begin{tabular}{|c|c|c|c|c|c|c|}
\hline \multirow{2}{*}{ Фактори } & \multicolumn{2}{|c|}{ Позначення } & \multirow{2}{*}{$\begin{array}{c}\text { Інтервал } \\
\text { варію- } \\
\text { вання } \\
\end{array}$} & \multirow{2}{*}{\multicolumn{3}{|c|}{$\begin{array}{l}\text { Рівні варіювання, } \\
\text { натуральні/кодовані }\end{array}$}} \\
\hline & $\begin{array}{l}\text { Нату- } \\
\text { ральні }\end{array}$ & $\begin{array}{c}\text { Кодо- } \\
\text { вані }\end{array}$ & & & & \\
\hline $\begin{array}{c}\text { Частота обертання } \\
\text { шнека } n_{k}, \text { об/хв }\end{array}$ & $X_{1}$ & $x_{1}$ & 100 & $100 /-1$ & $200 / 0$ & $300 /+1$ \\
\hline $\begin{array}{c}\text { Діаметр шнекового } \\
\text { конвеєра } D_{k}, \text { м }\end{array}$ & $X_{2}$ & $x_{2}$ & 0,04 & $0,12 /-1$ & $0,16 / 0$ & $0,2 /+1$ \\
\hline Крок шнека $T_{1}$, м & $X_{3}$ & $x_{3}$ & 0,03 & $0,05 /-1$ & $0,08 / 0$ & $0,11 /+1$ \\
\hline
\end{tabular}

Отримані результати продуктивності роботи $Q_{e . k}$ комбінованого гвинтового транспортера заносили у відповідні графи рандомізованої план- 
(C) Паньків В. P.

матриці проведення експериментальних досліджень. Обробку одержаних експериментальних даних проводили згідно з [12, с. 176-178].

Результати досліджень та їх обговорення. Апроксимуючу функцію, яка характеризує та функціонально описує зміну продуктивність роботи $Q_{e . k}$ комбінованого гвинтового транспортера, визначену експериментальним шляхом, знаходили у вигляді математичної моделі логарифмічної функції:

$$
Q_{e . k}=b_{o}+b_{1} \ln \left(n_{k}\right)+b_{2} \ln \left(D_{k}\right)+b_{3} \ln \left(T_{1}\right),
$$

де $Q_{e . k}-$ продуктивність роботи, кг/с; $b_{0}, b_{1}, b_{2}, b_{3}-$ коефіцієнти відповідних значень факторів; $n_{k}, D_{k}, T_{1}$ - відповідні натуральні фактори.

Натуральні значення коефіцієнтів рівняння регресії у вигляді функціонала $Q_{e . k}=f_{Q}\left(n_{k} ; D_{k} ; T_{1}\right)$ наведено у табл. 2.

\section{2. Натуральні значення коефіцієнтів рівняння регресії}

\begin{tabular}{|c|c|c|c|c|}
\hline \multirow{2}{*}{ Позначення } & \multicolumn{4}{|c|}{ Натуральні значення коефіцієнтів рівнянн регресії } \\
\cline { 2 - 5 } & $b_{0}$ & $b_{1}$ & $b_{2}$ & $b_{3}$ \\
\hline$Q_{e . k}=f_{Q}\left(n_{k} ; D_{k} ; T_{1}\right)$ & 0,74 & 0,59 & 1,26 & 0,32 \\
\hline
\end{tabular}

Після оцінки статистичної значущості коефіцієнтів рівняння регресії i перевірки адекватності моделі згідно 3 [12, с. 177-178], отримано рівняння регресії, яке характеризує зміну продуктивності роботи $Q_{e . k}$ комбінованого гвинтового транспортера у натуральних величинах:

$$
Q_{e . k}=0,74+0,59 \ln \left(n_{k}\right)+1,26 \ln \left(D_{k}\right)+0,32 \ln \left(T_{1}\right) .
$$

Рівняння регресії (4) характеризує зміну $Q_{e . k}$ залежно від основних параметрів шнекового конвеєра у наступних межах зміни вхідних факторів: частоти обертання шнека $100 \leq n_{k} \leq 300$ об/хв; діаметра шнека $0,12 \leq D_{k} \leq 0,2$ м; кроку шнека $0,05 \leq T_{1} \leq 0,11 \mathrm{M}$.

Згідно 3 рівнянням регресії (4) побудовано поверхню відгуку функціональної зміни продуктивності роботи $Q_{e . k}$ комбінованого гвинтового 
(C) Паньків В. P.

транспортера у вигляді функціонала: $Q_{e . k}=f_{Q}\left(n_{k} ; D_{k}\right)$, рис. $2 ; Q_{e . k}=f_{Q}\left(n_{k} ; T_{1}\right)$, pис. 3; $Q_{e . k}=f_{Q}\left(D_{k} ; T_{1}\right)$, рис. 4 .
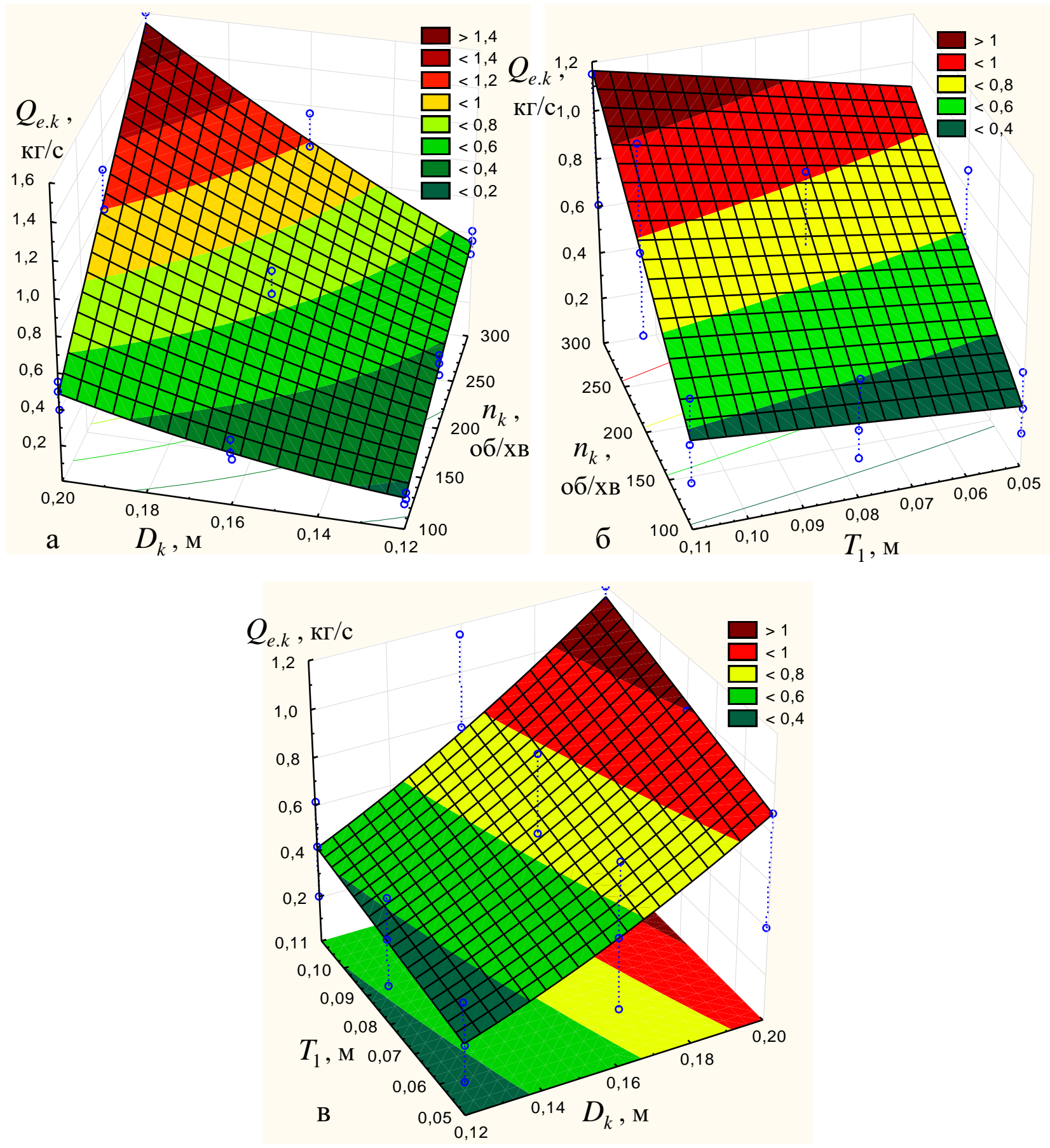

Рис. 2. Поверхня відгуку зміни продуктивності роботи $Q_{e . k}$ як функціонал: $\mathbf{a}-Q_{e . k}=f_{Q}\left(n_{k} ; D_{k}\right) ; \boldsymbol{\sigma}-Q_{e . k}=f_{Q}\left(n_{k} ; T_{1}\right) ; \mathbf{~ в - ~} Q_{e . k}=f_{Q}\left(D_{k} ; T_{1}\right)$

У заданих межах варіювання факторами, тобто частоти обертання шнека $n_{k}$ (від 100 до 300 об/хв), діаметра шнека $D_{k}$ (від 0,12 до 0,2 м), кроку шнека $T_{1}$ (від 0,05 до 0,11 м), зміна продуктивності роботи $Q_{e . k}$ комбінованого 
(C) Паньків В. P.

гвинтового транспортера, визначену експериментальним шляхом знаходиться в доволі значному діапазоні - від 0,11 до 1,6 кг/с, рис. 2.

Функціональна зміна продуктивності роботи $Q_{e . k}$ комбінованого гвинтового транспортера залежно від зміни факторів має прямо пропорційний характер - зі збільшенням $n_{k}, D_{k}$ і $T_{1}$ значення $Q_{e . k}$ також зростає, при цьому домінуючими факторами, які мають значний вплив на приріст продуктивності $€$ частота обертання шнека $n_{k}$ та діаметр шнека $D_{k}$, що характерно графічній інтерпретації поверхні відгуку, яку наведено на рис. 2.
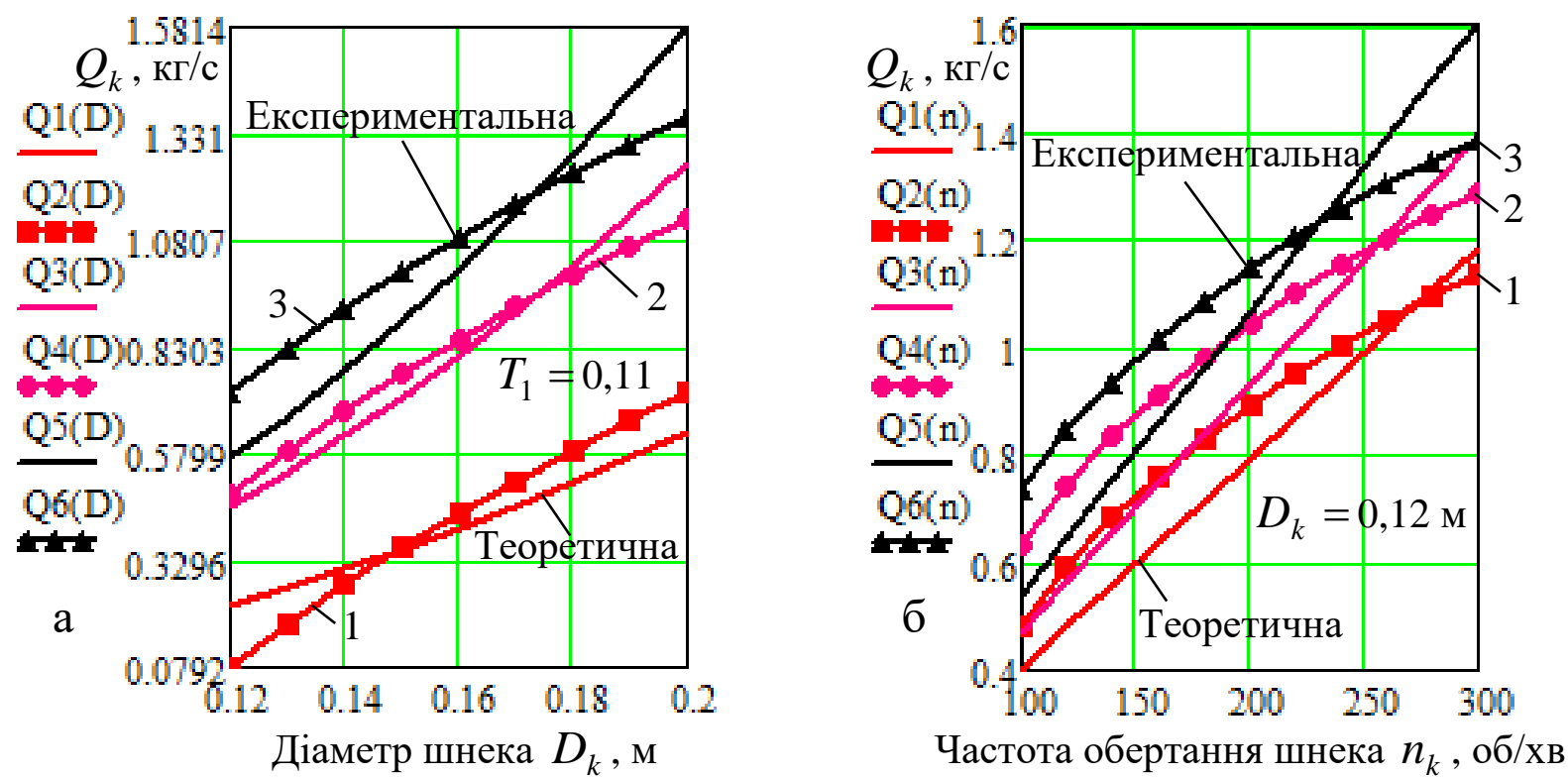

Рис. 3. Залежність зміни продуктивності роботи $Q_{e}$ як функціонал:

a $-Q_{k}=f_{Q}\left(D_{k}\right), 1,2,3-$ відповідно, $n_{k}=100 ; 200 ; 300$ об/хв;

б $-Q_{k}=f_{Q}\left(n_{k}\right), \mathbf{1}, 2,3-$ відповідно, $T_{1}=\mathbf{0 , 0 5} ; \mathbf{0 , 0 8} ; \mathbf{0 , 1 1}$ м

За збільшення діаметра шнека $D_{k}$ від 0,12 до 0,2 м продуктивність роботи $Q_{e . k}$ комбінованого гвинтового транспортера збільшується в середньому на 0,5...0,7 кг/с (рис. 3а), а за збільшення частоти обертання шнека $n_{k}$ від 100 до 300 об/хв - в середньому на 0,7 кг/с (рис. 3а, б), тобто прирости продуктивності роботи $Q_{e . k}$ в загальному контексті адекватні.

Приріст продуктивності роботи $Q_{e . k}$ комбінованого гвинтового 
(C) Паньків В. P.

транспортера в межах збільшення кроку шнека $T_{1}$ від 0,05 до 0,11 м дуже незначний - середнє значення приросту $Q_{e . k}$ знаходиться в межах $0,1 \ldots 0,15$ кг/с (рис. 3б).

Розбіжність експериментальних значень які побудовано згідно 3 рівнянням регресії (4) (залежності Q2(D), Q4(D), Q6(D)) та теоретичних значень $Q_{k}$ (залежності Q1(D), Q3(D), Q5(D)), які отримано на аналітичному рівні згідно з моделлю (2), а також, відповідно, Q2(n), Q4(n), Q6(n) та Q1(n), Q3(n), Q5(n), знаходиться у межах $5 \ldots 10 \%$, рис. 3 .

Висновки i перспективи подальших досліджень. На основі проведеного аналізу отриманих результатів можна стверджувати, що розроблена теоретична модель (2), яка на аналітичному рівні описує зміну продуктивності роботи $Q_{k}$ комбінованого гвинтового транспортера залежно від параметрів шнека адекватна рівнянню регресії (4), яке отримано на емпіричному рівні.

Розроблені аналітична (2) та емпірична (4) моделі можуть бути використані для подальшої оптимізації параметрів і режимів роботи гвинтових транспортних механізмів.

\section{Список літератури}

1. Дубровин В. Идентификация процесса разработки адаптированной корнеуборочной машины [текст] / В. Дубровин, Г. Голуб, В. Теслюк, В. Барановский // MOTROL. Commission of motorization and energetics in agriculture. An international journal on operation of farm and argil-food industry machinery. - Lublin-Rzeszow, 2013. - Vol. 15. - № 3. - C. 243-255.

2. Гевко Ів.Б. Науково-прикладні основи створення гвинтових транспортно-технологічних механізмів : автореферат дис. ... докт. техн. наук: 05.05.11 / Ів.Б. Гевко. - Львів, 2013. - 40 с.

3. Сільськогосподарські машини [текст] / Д.Г. Войтюк, Л.В. Аніскевич, В.М. Барановський [та інш.]. - К. : «Агроосвіта», 2015. - 679 с.

4. Hevko R.B. Mathematical model of the pneumatic-screw conveyor screw mechanism operation [text] / R.B. Hevko, V.O. Dzyura, R.M. Romanovsky // INMATEH. Agricultural engineering. - 2014. - Vol. 44. - No.3. - P. 103-110. 
(C) Паньків В. P.

5. Гевко І. Б. Гвинтові транспортно-технологічні механізми: розрахунок i конструювання [текст] / I. Б. Гевко. - Тернопіль : ТДТУ імені Івана Пулюя, 2008. - 307 c.

6. Рогатинський Р. Модель конструювання і вибору гвинтових конвеєрів 3 розширеними технологічними можливостями [текст] / Р. Рогатинський, І. Гевко // Вісник ТНТУ. - 2012. - № 3 (67). - C. 197-210.

7. Hevko R.B. The investigation of the process of a screw conveyer safety device actuation [text] / R.B. Hevko, O.M. Klendiy // INMATEH. Agricultural engineering. - 2014. - Vol. 42. -No.1. - P. 55-60.

8. Гевко I. Синтез змішувачів з гвинтовими робочими органами [текст] / I. Гевко, Р. Любачівський, А. Дячун // Вісник Львівського національного аграрного університету: агроінженерні дослідження. - 2012. - № 16. - С. 237246.

9. Рогатинський Р. Оптимізація параметрів гвинтових транспортнотехнологічних систем [текст] / Р. Рогатинський, І. Гевко, Л. Рогатинська // Вісник ТНТУ. - 2013. - № 1 (69). - С. 123-230.

10. Pankiv V.R. Investigation of constructive geometrical and filling coefficients of combined grinding screw conveyor [text] / V.R. Pankiv, O.A. Tokarchuk // INMATEH. Agricultural engineering. - 2017. - Vol. 51. -No.1/2017. P. 59-68.

11. Pankiv Vitalii. Throughput capability of the combined screw chopper conveyor [text] / Vitalii Pankiv // Вісник ТНТУ. - 2017. - № 1 (85). - C. 69-79.

12. 6. Шенк X. Теория инженерного эксперимента [текст] / Шенк X. - М.: Мир, 1972. - 374 с.

\section{References}

1. Dubrovyn V., Holub H., Teslyuk V., Baranovskyy V. (2013). Ydentyfykatsyya protsessa razrabotky adaptyrovannoy korneuborochnoy mashynы [Identification of the development process of the adapted root harvesting machine]. MOTROL. Commission of motorization and energetics in agriculture. An international journal on operation of farm and argil-food industry machinery. LublinRzeszow, 15, 3, 243-255.

2. Hevko Iv.B. (2013). Naukovo-prykladni osnovy stvorennia hvyntovykh transportno-tekhnolohichnykh mekhanizmiv [Scientific and Applied Fundamentals for the Creation of Screw Transport and Technological Mechanisms]: avtoreferat dys....dokt. tekhn. nauk: 05.05.11. Lviv, 40.

3. Silskohospodarski mashyny (2015). [Agricultural machines] / D.H. Voitiuk, L.V. Aniskevych, V.M. Baranovskyi [ta insh.]. K. : «Ahroosvita», 679.

4. Hevko R.B., Dzyura V.O., Romanovsky R.M. (2014). Mathematical model of the pneumatic-screw conveyor screw mechanism operation. INMATEH. Agricultural engineering, 44, 3, 103-110.

5. Hevko I. B. (2008). Hvyntovi transportno-tekhnolohichni mekhanizmy: rozrakhunok i konstruiuvannia [Screw transport and technological mechanisms: calculation and construction]. Ternopil : TDTU imeni Ivana Puliuia, 307. 
(C) Паньків В. P.

6. Rohatynskyi R., Hevko I. (2012). Model konstruiuvannia i vyboru hvyntovykh konveieriv z rozshyrenymy tekhnolohichnymy mozhlyvostiamy [Model of design and selection of screw conveyors with advanced technological capabilities]. Visnyk TNTU, 3 (67), 197-210.

7. Hevko R.B., Klendiy O.M. (2014). The investigation of the process of a screw conveyer safety device actuation. INMATEH. Agricultural engineering, 42, 1, $55-60$.

8. Hevko I., Liubachivskyi R., Diachun A. (212). Syntez zmishuvachiv z hvyntovymy robochymy orhanamy [Synthesis of faucets with screw working organs]. Visnyk Lvivskoho natsionalnoho ahrarnoho universytetu: ahroinzhenerni doslidzhennia, 16, 237-246.

9. Rohatynskyi R., Hevko I., Rohatynska L. (2013). Optymizatsiia parametriv hvyntovykh transportno-tekhnolohichnykh system [Optimization of the parameters of screw transport and technological systems]. Visnyk TNTU, 1 (69), 123-230.

10. Pankiv V.R., Tokarchuk O.A. (2017). Investigation of constructive geometrical and filling coefficients of combined grinding screw conveyor. INMATEH. Agricultural engineering, 51, 1/2017, 59-68.

11. Pankiv Vitalii (2017). Throughput capability of the combined screw chopper conveyor. Вісник ТНТУ, 1 (85), 69-79.

12. Shenk Kh. (1972). Teoryya ynzhenernoho эksperymenta [Theory of engineering experiment]. M.: Myr, 374.

\section{АНАЛИЗ ПРОЦЕССА ТРАНСПОРТИРОВАНИЯ МАТЕРИАЛА КОМБИНИРОВАННЫМ ВИНТОВЫМ ТРАНСПОРТЕРОМ}

\section{В. Р. Панькив}

Аннотация. Винтовые транспортеры, в качестве транспортных механизмов применяют в аграрной сфере производства, перерабатьвающей $и$ пищевой отраслях промышленности, специффика которых обусловлена наличием иирокой гаммы технологических процессов сбора и переработки продукции растениеводства. Совершенствование сущзествующих конструкичй винтовых транспортных механизмов и обоснование их рациональных параметров и режимов работь позволяет существенно повысить производительность работь и надежность выполнения технологических операций. Приведень результать аналитических и экспериментальных исследований комбинированного винтового транспортера-измельчителя корнеплодов, который выполненный в виде направляющзего кожуха в котором размещен шнековый конвейер, между витками которого установлено ножиизмельчители. За результатами экспериментальных исследований получено уравнение регрессии, которое характеризует изменение производительности работы усовершенствованного комбинированного винтового транспортера $в$ зависимости от параметров шнекового конвейера. Установлено, что в заданных пределах варьирования входных фракторов (частоть вращения шнекового конвейера $100 \leq n_{k} \leq 300$ об/мин; диаметра инекового конвейера 
(C) Паньків В. P.

$0,12 \leq D_{k} \leq 0,2 \mathrm{M} ;$ шага шнека 0,05 $\left.\leq T_{1} \leq 0,11 \mathrm{M}\right)$, производительность работьл находится в диапазоне от 0,5 до 5,0 кг/с. Результаты исследований являются дальнейшим шагом в разработке методики обоснования параметров транспортных машин.

Ключевые слова: инек, коэффицичент заполнения, горизонтальнылй конвейер, факторный эксперимент, эмпирическая модель, частота вращения, диаметр, шаг

\title{
ANALYSIS OF THE TRANSPORTATION PROCESS OF MATERIAL BY THE COMBINED SCREW CONVEYOR V. R. Pankiv
}

\begin{abstract}
Screw conveyors as transport mechanisms are used in the agrarian sphere of production, processing and food industries, the specifics of which are due to the presence of a wide range of technological processes of harvesting and processing of crop production. Improvement of existing structures of screw transport mechanisms and justification of their rational parameters and operating modes can significantly improve the productivity and reliability of the implementation of technological operations. Are presented the results of analytical and experimental research of the combined screw conveyor - shredder, which is executed in the form of a guide casing in which a screw conveyor is located, between which the knivesshredders are installed. According to the results of experimental research, obtained a regression equation, that characterizes the change in the performance of an advanced combined screw transporter depending on the parameters of the screw conveyor. It is established that in the given limits variation of input factors (speed of a screw conveyor rotation $100 \leq n_{k} \leq 300 \mathrm{rpm}$; the diameter of the screw conveyor $0,12 \leq D_{k} \leq 0,2 \mathrm{~m}$; step of the screw $0,05 \leq T_{1} \leq 0,11 \mathrm{~m}$ ), performance is in the range from 0,5 to $5,0 \mathrm{~kg} / \mathrm{sec}$. The research results are the next step in developing a methodology for justifying the parameters of transport vehicles.
\end{abstract}

Keywords: screw, fill factor, horizontal conveyor, factor experiment, empirical model, rotational speed, diameter, step 